\title{
THE EFFECT OF MONOMER OF REMOVABLE DENTURE BASE RESIN ON THE STRUCTURAL ORGANIZATION OF THE GLANDULAR ZONE OF ALBINO RAT HARD PALATE IN THE EXPERIMENT
}

10.36740/WLek202012120

\author{
Yevhenii S. Khilinich, Vadym Yu. Davydenko, Ivan I. Starchenko, Mykhailo Ya. Nidzelskyi, Hanna M. Davydenko, \\ Viktor V. Kuznetsov \\ UKRAINIAN MEDICAL STOMATOLOGICAL ACADEMY, POLTAVA, UKRAINE
}

\begin{abstract}
The aim: The paper presents the findings of the study of the 3 month-long effect of the monomer of the "Ftorax" denture base acrylic resin on the structural organization of the mucous membrane and the condition of the salivary glands of the albino rats' hard palate during the experiment.

Materials and methods: To achieve this goal, experimental studies involved mature rats, whose hard palate mucosa was smeared with 2\% aqueous solution of the monomer of the "Ftorax" denture base acrylic resin twice a day in the morning and evening. The animals were sacrificed on day 30 of the experiment and following 3 months.

Results: The findings of the studies of the structural organization of the mucous membrane and the analysis of the micropreparations of the mucous membrane of the hard palate of the animals of Group III have revealed substantial pathological changes both in the covering epithelium and in the lamina propria. The comparison between the intact animals and group of animals subjected to the 3 month-long effect of the monomer showed a significant thickening of the epithelial layer; a decrease in the mitotic index in the basal layer; impaired stratification of the cellular elements of the spinous layer; manifestations of exudative purulent inflammation, cystic and sclerotic changes in the excretory ducts; increase in the amount of connective tissue in the lobules of the salivary glands; decrease in the volume of the secretory parenchyma.

Conclusions: Based on the findings of the study we can conclude that the prolonged effect of the monomer of the denture base acrylic resins leads to disorder of the structural organization of the glandular zone of the hard palate; in its submucous layer the total volume of the salivary glands decreases, which, in turn, significantly reduces secretion and leads to hyposalivation.
\end{abstract}

KEY WORDS: structural organization, hard palate, salivary glands, secretion, monomer

Wiad Lek. 2020;73(12 p. I):2667-2671

\section{INTRODUCTION}

Many studies have been devoted to the negative effect of the monomer of removable laminar denture base acrylic resins on the oral tissues $[1,2,3,4]$. The authors have proved by evidence that the residual monomer, released into the oral fluid in the first months of denture wear, leads to significant lesions in the oral cavity. Our previous studies have established that the residual monomer led to disintegration of the taste receptors of the tongue, resulting in altered gustation $[5,6]$.

The oral cavity, oral fluid, prosthetic bed, removable laminar dentures is the unified system that ensures complete chewing and, therefore, it is important to study the effect of the monomer on the salivary glands of the oral cavity, especially the minor palatine ones, which are almost completely covered by the base of the maxillary removable dentures. However, the effect of the removable laminar denture bases, including the residual monomer, on the state of the minor salivary glands, which play an important role in maintaining the balance in the oral cavity, is poorly studied to date.

Our previous publications presented the findings of the studies of the state and structural organization of the mu- cous membrane of the hard palate of rats subjected to the 30-day-long effect of the monomer of denture acrylic resin during the experiment [7]. The follow-up experiment and observations will present the findings of the study of the longer effect of the monomer on the mucous membrane of the hard palate and minor salivary glands.

\section{THE AIM}

To study the 3 month-long effect of the monomer of the "Ftorax" denture base acrylic resin on the structural organization of the mucous membrane and the state of the salivary glands of the albino rats' hard palate in the experiment.

\section{MATERIALS AND METHODS}

19 laboratory Wistar rats, aged 1 to 1.5 years, were involved into the experimental study, carried out in the vivarium of the Ukrainian Medical Stomatological Academy. The animals were assigned into 3 groups: Group I (control; $n=5$ ) involved intact animals; Group II $(n=7)$ involved animals, subjected to the 30-day-long effect of the monomer on the 
mucous membrane of the hard palate; Group III $(n=7)$ involved animals, subjected to the 3-month-long effect of the monomer on the hard palate mucosa.

The contact was simulated by the smearing of the hard palate mucosa with $2 \%$ aqueous solution of the monomer of the "Ftorax" denture base acrylic resin twice a day in the morning and evening. The animals were sacrificed on day 30 of the experiment and following 3 months.

All studies were conducted in compliance with the rules of humane treatment of animals according to the requirements of the Tokyo Declaration of the World Medical Association and the general ethical principles of working with experimental animals, which were approved by the first National Bioethics Congress [8]. The Commission on Biomedical Ethics of the Ukrainian Medical Stomatological Academy has granted permission for experimental studies, as they meet the moral and ethical standards and basic provisions of the Council of Europe Convention on Human Rights and Biomedicine (minutes of the commission meeting as of 22.02.2018 No.162).

After euthanasia, each animal underwent removal of the hard palate, followed by division of the latter into two parts along the midline. One of the obtained fragments of the hard palate, together with the bone base, after 24-hour fixation in neutral $10 \%$ formalin, was decalcified for $2-4$ weeks, after which it was possible to obtain histological sections from the objects that contained bone tissue [9].

In the second fragment, the mucosa with the submucous layer was separated from the bone tissue using the lid scalpel under the control of a binocular magnifier. The fragments of the soft tissue were fixed in an upright state in neutral $10 \%$ formalin for 1-2 days.

The obtained samples, after conventional dehydration were embedded into liquid paraffin using the "Microm" station for paraffin blocks embedding. Sections of $5 \mu \mathrm{m}$ thick were obtained from the paraffin blocks on the "Leica" rotary microtome and stained with haematoxylin-eosin, using the conventional technique [10].

Visualization and imaging of the micropreparations was made by the Olimpus BX-41 microscope equipped with digital microphoto attachment and licensed software package.

\section{RESULTS}

The findings of the studies of the structural organization of the mucous membrane and the analysis of the micropreparations of the mucous membrane of the hard palate of the animals of Group III have revealed substantial pathological changes both in the covering epithelium and in the lamina propria of the mucous membrane. The comparison between the intact animals and group of animals, subjected to the 3 month-long effect of the monomer, showed a significant thickening of the epithelial layer, accounted on the average to $210 \pm 9,4 \mu \mathrm{m}$. Notably, all observations have shown that the epithelial layer was characterized by significant variations of this parameter in different areas, leading to alternating areas with dramatically increased epithelium thickening and areas of its thinning, with the latter occupying small area.
Similar to the previous experimental group, the cells of the basal layer were arranged in a single layer, the areas with twoand three-layer arrangement of epitheliocytes were rather rare. The morphometry has established that the mitotic index in the basal layer decreased significantly compared with the previous experimental group, accounting to $17 \%$.

No significant changes in the spinous layer of the covering epithelium have been noted compared with experimental Group II. Periodically, keratin cysts were formed, epithelial cells with the signs of hydropic dystrophy were found in slightly larger amount, and intraepithelial leukocytes were also visualized among the epitheliocytes of the basal and spinous layers.

Admittedly, impaired stratification of the cellular elements and prominent polymorphism, manifested by both altered tinctorial properties of the epithelial cells and some deviations from the typical size and shape of the latter, as well as the increase in the number of dystrophically altered epitheliocytes should be considered as a distinctive feature of the structural organization of the spinous layer of the covering epithelium in the above group of the experimental animals.

The granular layer was intact, and, similar to the abovementioned group, was represented by several layers of the oblate cells with the presence of fine granules of keratohyalin in the cytoplasm of the latter (Fig. 1).

The corneous layer was slightly thickened and according to the measurements, the thickness of the latter was $44 \pm 2.1 \mu \mathrm{m}$ compared with experimental Group II. A distinctive feature in the structure of the corneous layer of the covering epithelium in the animals of this experimental group was the presence of significant lengthy areas in which, in addition to the typical horny plates, the deformed epitheliocytes with pyknotically altered, often fragmented nuclei, were visualized (Figure 1).

The described areas, which were most often identified in the zones of thickening of the covering epithelium, indicated about the disorder of keratinization process of the incomplete keratinization type. These changes cannot be fully regarded as a full-fledged manifestation of the compensatory-adaptive response, since in this case no formation of a continuous "horny shield" was noted with any significant barrier structure for the penetration of pathogenic chemical agent into the lamina propria of the mucous membrane. However, the changes described above probably indicate the onset of the phase of depletion of the compensatory mechanism, which was formed earlier.

Noteworthy, a larger number of observations showed epithelial complexes quite variable in size, which were rather deeply immersed into connective tissue of the lamina propria of the mucous membrane and have no visible relationship with the layer of covering epithelium. These structures were presented by acanthotic bands of the covering epithelium, as evidenced by the data obtained in the study of serial histological sections. In turn, the formation of such structures indicates a disorder of epithelial proliferation, when no formation of a continuous epithelial layer occurs, which may be associated both with the effect of external stimuli and pathological changes in the underlying connective tissue. 


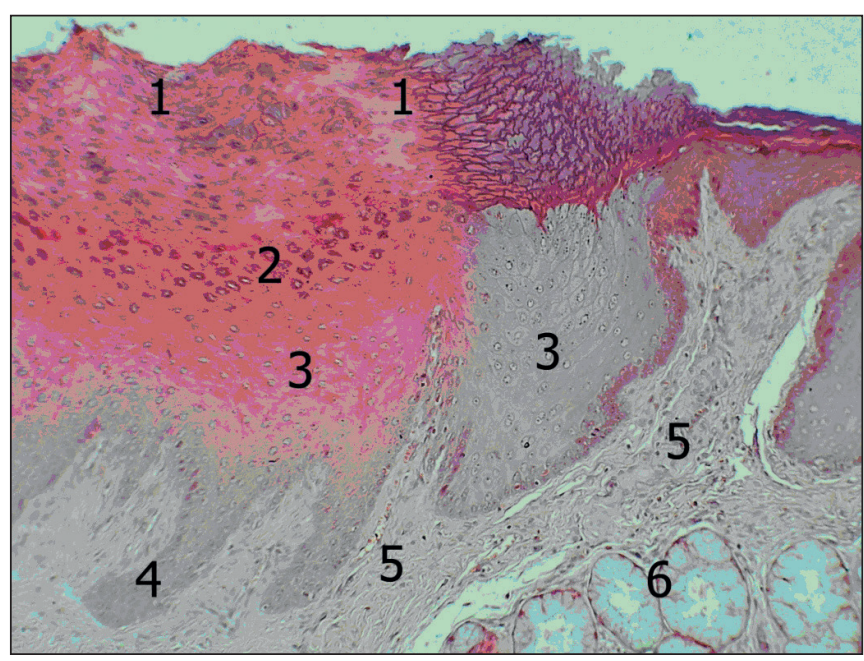

Fig. 1. Mucous membrane of the glandular zone of the hard palate (experimental Group III). H\&E stain. Lens: 10xmagnification, ocular lens: $10 \times$ magnification.

1 - corneous layer; 2 - glandular layer; 3 - spinous layer with altered tinctorial properties; 4 - acanthotic bands; 5 - papillary layer of the lamina propria of the mucous membrane; 6 - acini of the palatine salivary glands.

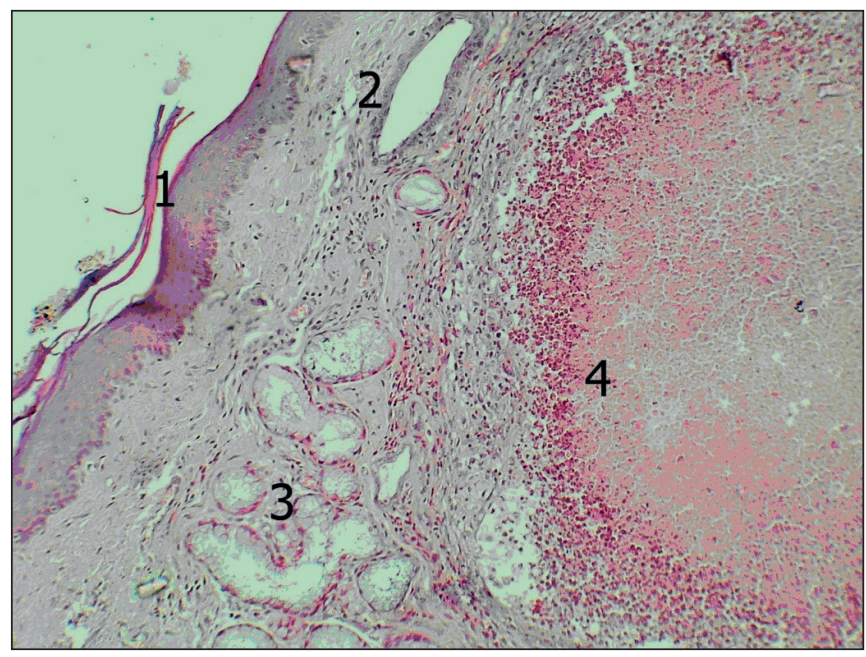

Fig. 2. Mucous membrane of the glandular zone of the hard palate (experimental Group III). H\&E stain. Lens: 10×magnification, ocular lens: 10×magnification.

1 - covering epithelium; 2 - dilated excretory duct of the palatine salivary gland; 3 - acini of the salivary glands; 4 - acute abscess in the lamina propria of the mucous membrane

Pathological changes found in the lamina propria of the mucous membrane of the hard palate can be regarded as confirmation of this assumption. First of all, it should be noted that extensive orbicular necrotic areas were noted in the lamina propria of experimental animals of Group III, which occupied both papillary and reticular layers, abundantly infiltrated with neutrophilic polymorphonuclear leukocytes; some of them were destroyed. The described picture corresponds to the onset of acute abscess, which is one of the morphological forms of manifestation of exudative purulent inflammation (Figure 2).

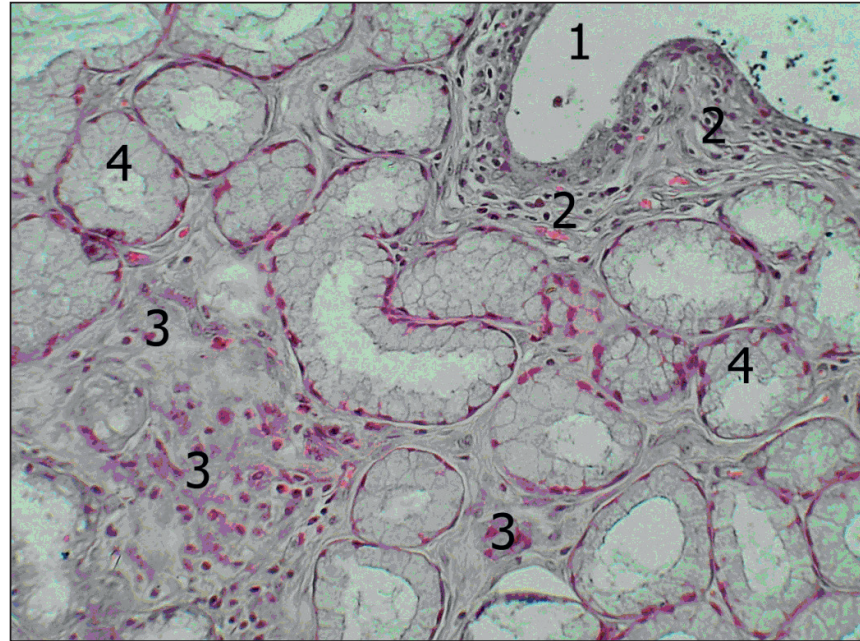

Fig. 3. Palatine salivary gland (experimental Group II). H\&E stain. Lens:

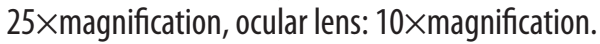

1 - dilated excretory duct; 2 - proliferation of the connective tissue and cellular infiltration around the excretory duct; 3 - proliferation of the connective tissue and cellular infiltration in the glandular lobules; 4 - acini.

We hypothesize that origination of acute abscesses in the lamina propria of the mucous membrane should be regarded as the complication, primarily associated with the weakening of the barrier properties of the covering epithelium, which greatly facilitates the contact penetration of pathogenic microflora from the oral cavity into the connective tissue of the lamina propria of the mucous membrane.

Obviously, purulent inflammatory lesions described above are associated with a decrease in both local and general immunity due to the long-term adverse effects of the chemical agent on the body of experimental animals.

In other cases, in the papillary layer of the lamina propria, changes typical of the chronic inflammatory process were noted, manifested by moderate vascular plethora, presence of diffuse cellular infiltrates with a predominance of lymphocytes and plasma cells. Significant amount of eosinophilic leukocytes were also found in the inflammatory infiltrates. Flattening and deformation of connective tissue papillae, containing homogeneous cell-free zones, were often found, which indicated the development of sclerotic and atrophic processes.

Changes in the reticular layer of the lamina propria were almost similar to the previous experimental group and were characterized by the significant amount of diffuse infiltration of cellular elements of the monocyte-macrophage type, lymphocytes, plasma cells, neutrophils and eosinophilic leukocytes. Periodically, in the deeper segments of the reticular layer, the areas with increased amount of mostly mature fibroblasts were found. Probably, this circumstance may indicate the initiation of the process of collagenation, which is known to underlie sclerotic changes.

Marked changes, compared with the previous experimental group, were found in the palatine salivary glands. Thus, first of all, the presence of significantly expanded areas with a prominent flattening of the epithelial lining in the larger excretory ducts was noteworthy (Figure 3 ). 
Apparently, the cystic alterations found in the excretory ducts were primarily caused by inflammation, as evidenced by the presence of cellular infiltrates in the periductal connective tissue. At the same time, in all cases the apparent thickening of the layers of connective tissue around larger and medium-sized excretory ducts was prominent, indicating the development of sclerotic processes in the salivary glands that can lead to mechanical compression of the ducts with formation of cysts more proximal to a compression site.

The findings of the morphometric studies have revealed increased amount of connective tissue in the lobules of the salivary glands, accounting for $73 \%$; the relative volume of the secretory parenchyma was accounted for $27 \%$.

In the acini of the salivary glands the number of secretory epitheliocytes with altered tinctorial properties increased, compared with the previously described experimental group, which may indirectly indicate a decrease in their secretory activity.

In general, in the submucous layer of the hard palate, the total volume of the salivary glands was $67.6 \%$, which is significantly less than in the previous experimental group. The volume of the connective tissue accounted for the remaining $32.4 \%$.

\section{DISCUSSION}

It has been established that prolonged action of the monomer of the denture base acrylic resin adversely affects the structural organization of the glandular zone of the hard palate of albino rats. Following the 3 month-period, the experimental animals showed substantial pathological changes both in the covering epithelium and in the lamina propria of the mucous membrane, namely, origination of acanthotic bands, indicating a disorder of epithelial proliferation, when no formation of a continuous epithelial layer occurs; the presence of extensive necrotic areas in the lamina propria of some experimental animals, infiltrated with neutrophilic polymorphonuclear leukocytes. Some of the leukocytes were destroyed, indicating the onset of acute abscess, which is one of the morphological forms of manifestation of exudative purulent inflammation.

The findings of the study have found that inflammation becomes chronic within 3 months, leading to the changes in the salivary glands of the hard palate that are manifested by the cysts, formed in the excretory ducts. We hypothesized that the formation of such cysts was mainly caused by inflammatory changes in the ducts, mechanical deformation, accompanied by a narrowing of the lumen of the latter, as well as changes in the physicochemical properties of the product of secretion.

Many researchers report on the onset of pathological lesions in the hard palate mucosa, and especially in the minor salivary glands, under the impact of various factors $[4,11,12]$. The findings of their studies have found that the action of residual monomer leads to dilatation of the excretory ducts of minor salivary glands, destructive changes in the glands, which, in turn, reduces their secre- tory activity; the ratio of the parenchyma to the stroma of salivary glands changes. Similar changes in the secretory activity of the salivary glands were reported by other authors [13], who proved that the phenomena of galvanosis lead to its significant reduce.

\section{CONCLUSIONS}

1. The prolonged effect of the monomer of the "Ftorax" denture base acrylic resin on the rat hard palate mucosa leads to a significant pathological processes, namely, thickening of the epithelial layer; a decrease in the mitotic index in the basal layer; impaired stratification of the cellular elements of the spinous layer and the events of their polymorphism; the onset of acute abscesses in the lamina propria of the mucous membrane as the manifestations of exudative purulent inflammation.

2. 3 month-long effect of the monomer leads to a significant pathological lesions in the palatine salivary glands, namely, cystic and sclerotic changes in the excretory ducts; increased amount of connective tissue in the lobules of the salivary glands; decrease in the volume of the secretory parenchyma; decrease in secretory activity of palatine salivary glands due to increased amount of secretory epitheliocytes with altered tinctorial properties.

3. In general, in the submucous layer of the hard palate, the total volume of the salivary glands was significantly reduced, accounting for $67.6 \%$.

\section{REFERENCES}

1. Bykov I.M., Akopova L.V., Skorikova L.A. Biokhimicheskiye pokazateli gomeostaza i biotsinoza polosti rta u patsiyentov s proteznym stomatitom [Biochemical indicators of oral cavity homeostasis and biocinosis in patients with prosthetic stomatitis]. International Journal of Applied and Basic Research. 2015; 3:517-523. (in Russian).

2. Senchakovych YU.V., Yeroshenko H.A., Kazakova K.S., Bilash S.M. Vplyv metakrylatu na funktsiyu slynnykh zaloz [The effect of methacrylate on the function of the salivary glands]. The world of medicine and biology. 2014; 1 (43): 181-185. (in Ukrainian).

3. Pervov Yu.Yu. Vliyaniye s"yemnykh akrilovykh zubnykh protezov na immunnyy gomeostaz slizistoy obolochki polosti rta v zavisimosti ot primenyayemykh materialov $i$ konstruktsiy [The effect of removable acrylic dentures on the immune homeostasis of the oral mucosa depending on the materials and structures used]. Kazan Medical Journal. 2012; 93 (2): 227-230. (in Russian).

4. Romanova Yu. G. Vliyaniye patologicheskogo narusheniya gomeostaticheskikh sistem polosti rta na sroki adaptatsii ks"yemnym akrilovym zubnym protezam [Influence of pathological disorders of homeostatic systems of the oral cavity on the timing of adaptation to removable acrylic dentures]. Reaching the biology of medicine. 2012; 2 (20): 54-57. (in Russian).

5. Davydenko V.Yu. Vplyv zalyshkovoho monomera bazysiv znimnykh plastynkovykh proteziv na stan smakovykh retseptoriv ta smakovu chutlyvist' [Influence of residual monomer of removable plate prosthesis bases on the state of taste receptors and taste sensitivity]. "Medical science in health care practice": materials of the all-Ukrainian scientific-practical conference. Poltava, 2015:7. (in Ukrainian). 
6. Davydenko V, Starchenko I, Davydenko A, Trufanova V, Kuznetsov V. The impact of the acrylic monomer on the morphological structure of rat lingual mucosa. Georgian medical news. 2018;5(278):146-151.

7. Khilinich Ye., Starchenko I, Davydenko V, Nidzelskiy M, Davydenko G. Condition and structural organization of the glandular area mucous membrane of albino rat hard plate under the 30-day-long effect of acrylic monomer. World of medicine and biology. 2020;1(71):216-220.

8. Obshchiye eticheskiye printsipy rabotys eksperimental'nymi zhivotnymi pri provedenii meditsinskikh biologicheskikh issledovaniy [General ethical principles of working with experimental animals in medical biological research]. Natsíonal'niy kongress z bíoyetiki (Kiißv, 17-20 veresnya 2001r.). Journal of the National Academy of Medical Sciences of Ukraine. 2001; 7(4):814-816. (in Russian).

9. Korzhevskiy D. E., Gilyarov A. V. Osnovy gistologicheskoy tekhniki [Fundamentals of histological techniques]. SPb. : SpetsLit. 2010:95. (in Russian).

10. Bagriy MM, Dibrova VA, Popadynets OG, Grishchuk MI. Metodyky morfolohichnykh doslidzhen' [Methods of morphological research]. Vinnytsia: New book. 2016:328. (in Ukrainian).

11. Senchakovich Yu.V., Kazakova KS, Yeroshenko GA. Suchasni pohlyady na prychyny dysfunktsiyi slynnykh zaloz [Modern views on the causes of salivary gland dysfunction]. The world of medicine and biology. 2013; 9 (4-1):112 - 116. (in Ukrainian).

12. Sherstyuk 0.A., Svintsitskaya N.L., Pilyugin A.V. Issledovaniye stromy, parenkhimy i ikh vzaimootnosheniy v malykh slyunnykh zhelezakh cheloveka [Study of the stroma, parenchyma and their relationship in the small salivary glands of a person]. Ukrainian morphological almanac. 2010; 3:156-157. (in Russian).

13. Timofeev A.A. Sekretornaya funktsiya bol'shikh i malykh slyunnykh zhelez pri gal'vanizme i gal'vanoze [The secretory function of large and small salivary glands in galvanism and galvanosis]. Modern dentistry. 2013; 3: 72-76. (in Russian).
The paper has been written within the research scientific work, entitled "The effect of dental constructs and material on the prosthetic bed and adaptive abilities of the body", State registration No. 0116U004188, performed at the Department of Postgraduate Education of Prosthodontists of Ukrainian Medical Stomatological Academy.

\section{ORCID and contributionship:}

Yevhenii S. Khilinich: 0000-0001-7970-944X ${ }^{D}$

Vadym Yu. Davydenko: 0000-0002-4231-7343 ${ }^{B}$

Ivan I. Starchenko: 0000-0002-6666-1448 ${ }^{\mathrm{E}}$

Mykhailo Ya. Nidzelskyi: 0000-0002-5629-0719 ${ }^{F}$

Hanna M. Davydenko: 0000-0001-6219-2376 ${ }^{A}$

Viktor V. Kuznetsov: 0000-0002-6707-830X ${ }^{\mathrm{C}}$

\section{Conflict of interest:}

The Authors declare no conflict of interest

\author{
CORRESPONDING AUTHOR \\ Vadym Yu. Davydenko \\ Department of Postgraduate Education of Prosthodontists \\ Ukrainian Medical Stomatological Academy \\ St. Shevczenka 23, Poltava, Ukraine \\ tel: +380507321085 \\ e-mail: davydenko.a24@gmail.com
}

Received: 21.08 .2020

Accepted: 27.11 .2020

A - Work concept and design, B - Data collection and analysis, C - Responsibility for statistical analysis,

D -Writing the article, $\mathbf{E}$ - Critical review, $\mathbf{F}$ - Final approval of the article 